\title{
Rajakarjalaismurteiden avoimet persoonaviittaukset
}

\author{
Milla Uusitupa
}

\section{Väitöksenalkajaisesitelmä Itä-Suomen yliopistossa 15. joulukuuta 2017}

Kuten lukuisat väitöskirjan tekijät ennen minua myös minä olen saanut tutkimusprojektini aikana vastata monta kertaa kysymykseen, mitä tutkimukseni oikein käsittelee. Yksi tutkimusaihettani sivuava esimerkki on osoittautunut lyömättömäksi tavaksi havainnollistaa, millaisen ilmiön parissa olen viimeiset vuodet puuhastellut. Kun esitän seuraavan Mika Häkkisen suuhun laitetun sitaatin, kyselijä on yleensä tyytyväinen ja nyökyttelee ymmärtävänsä, mistä yksikön 2. persoonan eli sinä-muodon yleistävässä käytössä on kyse: "Kun sä ajat formulaa, sä et ajattele mitään muuta." Selvää on, ettei kilpakuljettaja puhu keskustelukumppaninaan toimivasta haastattelijasta vaan havainnollistaa omaa kokemustaan siitä, millaista kilpa-ajaminen on ja mitä se vaatii. Tällaista yksikön 2. persoonan käyttöä kutsun väitöskirjassani yksikön 2. persoonan avoimeksi käytöksi.

Urheilu-uutisten lisäksi yleistävään sinä-puheeseen törmää aika ajoin myös mielipidepalstoilla. Ilmaisukeinoa on kuvailtu milloin ärsyttäväksi, epäkohteliaaksi ja tunkeilevaksi, milloin suomelle vieraaksi ja muista kielistä omaksutuksi kielenkäyttötavaksi. Suomen kielen tutkijoiden keskuudessa on kuitenkin ollut jo pitkään tiedossa, ettei yksikön 2. persoonan avoin käyttö ole vanhastaan täysin vierasta suomen murteissakaan. Jo Uuno Taavi Sireliuksen (1894) Jääsken ja Kirvun murretta käsittelevässä tutkimuksessa esitellään koko joukko esimerkkilauseita, joissa puhuja ei yksikön 2. persoonalla viittaa spesifisti kuulijaan vaan kuvailee yleisemmin jonkinlaisessa tilanteessa olemista.

(1) Näist puatiloist ku määt ostamaa ryynit, ni ne o’ kalliimmat ku hersryynit ['hirssisuurimot'].

(2) Kaks turkulaista haastaat keskenää - a et ymmärrä. (Sirelius 1894: 113.) 
Esimerkki 1 kertoo lainalaisuuden, joka pätee kehen tahansa puheena olevissa kaupoissa asioivaan ryynien ostajaan. Esimerkki 2 puolestaan havainnollistaa, miten vaikeaa kaakkoissuomalaisen on saada selvää kahden turkulaisen välisestä keskustelusta: 'kaksi turkulaista kun keskustelee, niin sitä ei voi ymmärtää.

Perusteellista tutkimusta yksikön 2. persoonan avoimesta käytöstä kaikissa suomen murteissa ei ole toistaiseksi julkaistu, mutta 1800- ja 1900-lukujen vaihteessa ilmestyneet murresyntaksin tutkimukset (Setälä 1883; Cannelin 1889; Sirelius 1894; Latvala 1894, 1899; Kannisto 1902), 200o-luvulla valmistuneet opinnäytetyöt (Kuparinen 2009; Surakka 2011; Uusitupa 2011) ja muut selvitykset (Forsberg \& Uusitupa 2015) ovat antaneet tukea käsitykselle, että yksikön 2. persoonan avoin käyttö on vanhastaan tunnettu suomen itämurteissa ja erityisesti kaakkoismurteissa, mutta suomen länsimurteissa ja etenkään lounaismurteissa ilmaisukeinoa ei ole juuri käytetty.

Väitöstutkimuksessani olen verrannut yksikön 2. persoonan avointa käyttöä nollapersoonaan, ilmaisukeinoon, jolla tarkoitetaan suomen kielen tutkimuksessa sellaisia yksikön 3. persoonan muotoisia lauseita, joissa ei ole ilmisubjektia eli tekijää ilmaisevaa pronominia tai substantiivia mutta joilla voidaan avoimen yksikön 2. persoonan tapaan puhua henkilötarkoitteisen kokijan tai toimijan kokemuksesta avoimesti (Laitinen 1995; ISK 2004: \$ 1347-1365). Kielitoimiston ohjepankista poimitun esimerkin Kun tätä kirjaa lukee, alkaa nukuttaa voi siis toisin sanoen ajatella pätevän kehen tahansa, joka tarttuu puheena olevaan teokseen. Toisin kuin avoin yksikön 2. persoona nollapersoona tunnetaan laajasti kaikissa suomen murteissa, ja se kuuluu neutraalina avoimuuden ilmaisukeinona myös suomen yleiskieleen. Yle-uutisista poimitut esimerkit Vappusimat ehtii vielä valmistaa pikaversiona (Manu 2017) ja Joko länsimetron kyytiin viimein pääsee? (Koivuranta 2017) ilmaisevat siis molemmat toimintaa, joka on mahdollista kenelle tahansa siman ystävälle tai metromatkustajalle.

Väitöstutkimukseni Rajakarjalaismurteiden avoimet persoonaviittaukset edustaa funktionaalista murresyntaksin tutkimusta, ja sen kohteena on suomen ja karjalan kielen persoonajärjestelmät, erityisesti yksikön 2. ja 3. persoona. Edellisten esimerkkien kaltaisia yleistäviä yksikön 2. ja 3. persoonan lauseita kutsun työssäni avoimiksi persoonaviittauksiksi, koska niillä puhuja ei puhu kenestäkään tietystä henkilöstä vaan yleisemmin jonkinlaisessa tilanteessa olevasta, useimmiten henkilötarkoitteisesta kokijasta tai toimijasta. Olen tarkastellut työssäni avoimen tulkinnan saavia yksikön 2. ja 3. persoonan lauseita rajakarjalaismurteissa, joilla tarkoitetaan kielimuotoja, joita puhuttiin ennen vuosien 1939-1944 sotia Laatokan pohjoispuolisessa Raja-Karjalassa Salmissa, Suistamolla, Suojärvellä, Impilahdella ja Korpiselässä sekä Ilomantsin ja Soanlahden itäosissa (ks. kartta 1 seur. sivulla).

Raja-Karjalan alueella puhuttiin ennen toista maailmansotaa sekä karjalaa että suomea, ja alueen kielimuotoja on kutsuttu kirjallisuudessa muun muassa Raja-Karjalan siirtymä-, raja- ja välimurteiksi (tarkemmin Uusitupa, Koivisto \& Palander 2017). Karjalan kieli on suomen lähin sukukieli, jolla on erityisen paljon yhteistä suomen itämurteiden kanssa. Läheisestä kielisukulaisuudestaan huolimatta esimerkiksi suomen ja karjalan tavoissa ilmaista persoonaa on kuitenkin merkittäviä eroja. Tämän tutkimuksen kannalta erityisen merkittävää on, että siinä missä nollapersoona on kaikille suomen murteille tyypillinen tapa ilmaista viittaussuhteen avoimuutta, karjalassa ensi- 
sijainen avoimuuden ilmaisukeino onkin yksikön 2. persoona. Rajakarjalaismurteissa, joissa yhdistyy piirteitä sekä suomen että karjalan kielestä, on käytetty yleisesti molempia ilmaisukeinoja. Eräs väitöstutkimukseni tulos on, että nollapersoonan ja avoimen yksikön 2. persoonan keskinäistä vaihtelua rajakarjalaisaineistossa selittää se, mistä päin Raja-Karjalaa puhuja on kotoisin. Puhuja käyttää keskimäärin sitä enemmän yleistäviä sinä-lauseita, mitä idempää ja lähempää karjalan kielen sydänalueita hän on kotoisin. Vastaavasti nollapersoonan käyttö on sitä yleisempää, mitä lännempää ja lähempää suomen itämurteiden puhuma-alueita puhuja on kotoisin.

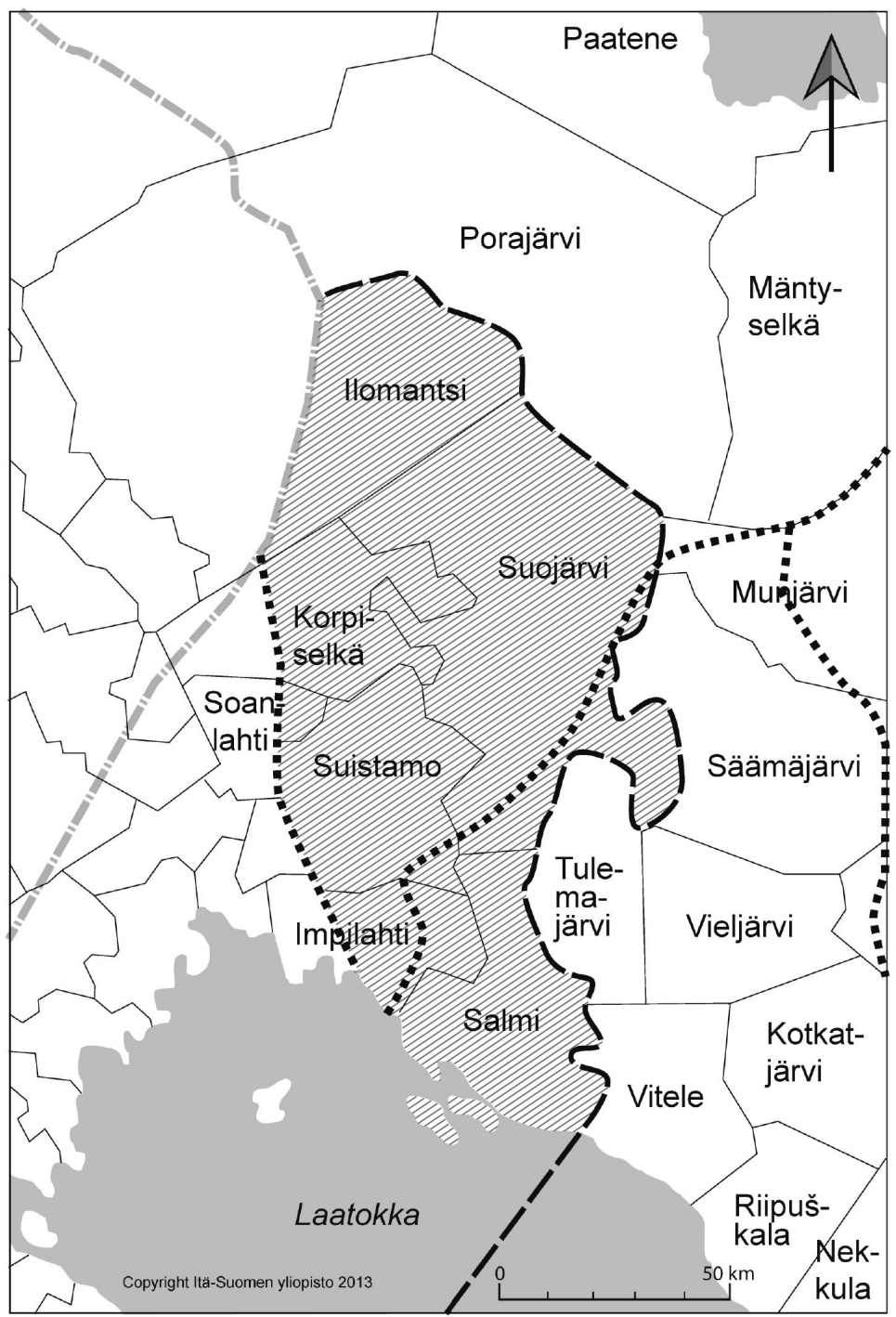

Kartta 1.

Kielitieteellisesti määritelty Raja-Karjala (harmaalla viivoitettu alue). 
Toisin kuin suomen nykypuhekielessä, jossa yleistävissä sinä-ilmauksissa esiintyy usein persoonapronomini $s \ddot{a}$, rajakarjalaismurteissa tai muissa karjalan varieteeteissa persoonapronominia sinä tai sie ei käytetä, vaan ilmauksen kieliopillista persoonaa merkitään ainoastaan predikaattiverbillä. Esimerkissä 3 puhuja havainnollistaa, miten paljon menneisyydessä arvostettiin työn tekoa: 'mitä enemmän teki töitä [raskaana ollessakin], sitä parempi'. Ensimmäinen lause ei sisällä persoonapronominia, vaan lauseen kieliopillinen persoona näkyy predikaatista ruavoit 'teit töitä.

(3) midä enemmän ruavoit, sen oli parempi (IMPILAHTI 5129:2)².

Samanlaisia merkitykseltään yleistäviä mutta muodoltaan persoonapronominittomia yksikön 2. persoonan lauseita voi löytää myös vaikkapa sanomalehtiteksteistä. Esimerkki 4 sisältää yksikön 2. persoonan muotoisen yhdyslauseen, joka on referenssiltään avoin ja ilmaisee, ettei koulutustausta ole puhujan mukaan ainakaan ainoa sivistyksen mittari.

(4) Onko se ainut sivistyksen ehto, että on akateeminen tutkinto? Voit olla ihan tonttu, vaikka olisit tohtori, huomauttaa Tuija Vähävuori. (Koivisto 2013.)

Karjalan kielen päämurteet ovat perinteisen murrejaon (esim. KKS) mukaan livvinkarjala ja varsinaiskarjala, joka jakaantuu edelleen pohjoisempana puhuttavaan vienankarjalaan ja eteläkarjalaan (kartta 2 seur. sivulla). Lisäksi omiksi karjalan murteikseen luetaan Sisä-Venäjällä Tverin, Tihvinän ja Valdain alueilla puhutut ja osin edelleen puhuttavat karjalan saarekemurteet. Raja-Karjalan alueella puhuttiin karjalan eri murteista eteläkarjalaa ja livvinkarjalaa, ja myös tutkimukseni karjalankielinen tiivistelmä edustaa nimenomaan livvinkarjalaa. Kartassa 1 livvinkarjalan ja eteläkarjalan välistä murrerajaa osoittaa pisteviiva, joka lähtee Laatokasta Impilahden kohdalta hieman mutkitellen kohti koillista. Kohti luodetta lähtevä pisteviiva puolestaan osoittaa rajakarjalaismurteiden ja suomen itämurteiden välistä kielirajaa. Kartan 1 oikeassa reunassa kulkeva pisteviiva erottaa livvinkarjalan ja lyydin perinteisiä puhuma-alueita.

Toisen maailmansodan päättyessä Suomessa on arvioitu eläneen noin 50 ooo60 ooo karjalan kielen puhujaa, ja heistä valtaosa asui Raja-Karjalassa (Sarhimaa 2017: 112-113). Tuolloiseen Suomen väkimäärään suhteutettuna karjalankielisiä oli noin 1,5 prosenttia koko Suomen väestöstä (mts. 115). Pääosa karjalan kielen puhujista on elänyt ja elää edelleen Venäjällä Karjalan tasavallassa. Kuitenkin myös Suomessa elää yhä tuhansia karjalankielisiä. Arviot Suomen karjalanpuhujien nykyisestä määrästä vaihtelevat viidestä tuhannesta noin yhteentoista tuhanteen. Tarkkoja lukumääriä on vaikea ilmoittaa, koska Suomen karjalankielisistä ei ole miltään ajalta olemassa virallisia väestönlaskentatietoja. (Mts. 112-114.) Toisinaan voikin olla havainnollisempaa puhua karjalan kielen puhujien sijaan Suomen karjalankielisestä yhteisöstä. Anneli Sarhimaan (mts. 114) mukaan Suomen karjalankielinen yhteisö on Karjalan Kielen Seuran

1. Viittaan Raja-Karjalan korpuksesta keräämääni tutkimusaineistoon haastateltavan kotipitäjän nimellä ja haastattelun arkistosignumilla. 
käyttämä käsite, jolla tarkoitetaan karjalan kielen aktiivipuhujien lisäksi kaikkia sellaisia, joilla on karjalankieliset juuret tai jotka muuten identifioituvat Suomen karjalankieliseen väestöön, vaikka he eivät itse puhuisi karjalaa tai osaisivat kieltä vain vähän tai eivät lainkaan. Tällä tavoin määriteltyyn Suomen karjalankieliseen yhteisöön kuuluu Karjalan Kielen Seuran arvion mukaan nykyään noin 30 ooo henkilöä (mts. 114-115).

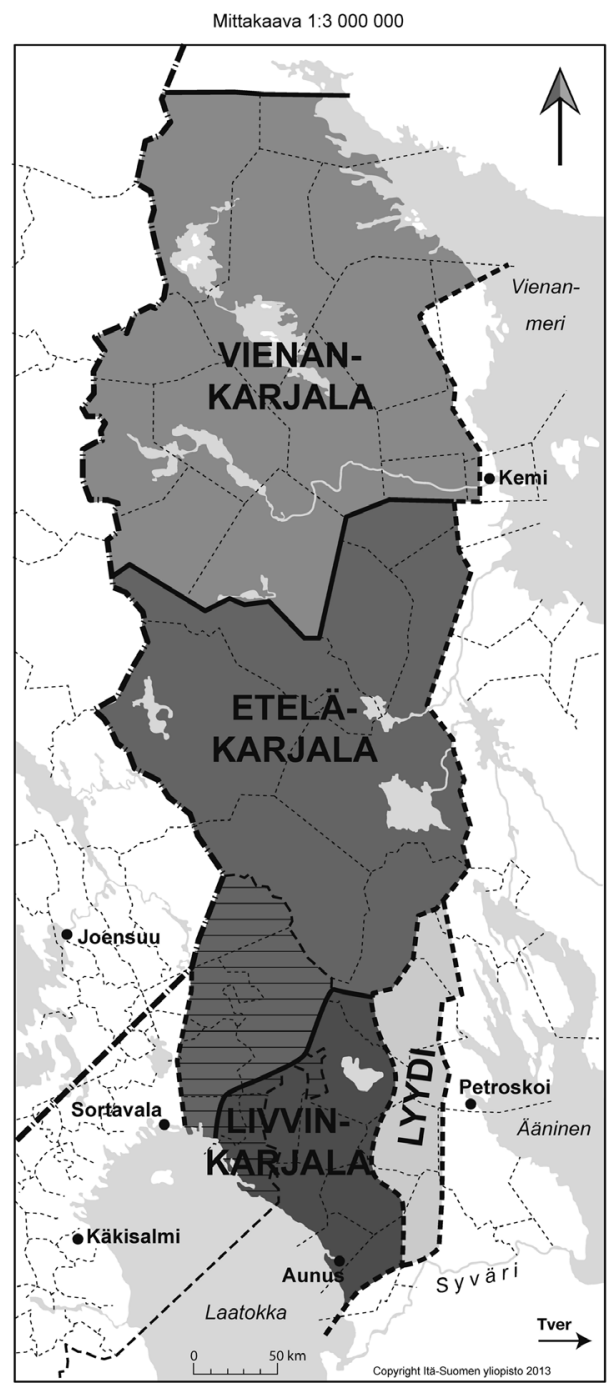

Kartta 2.

Karjalan kielen eri varieteetit eli vienankarjala, eteläkarjala, rajakarjala (viivoitettu alue) ja livvinkarjala sekä lyydi.

Raja-Karjalassa eli ennen toista maailmansotaa paitsi karjalan myös suomen murteiden puhujia. Alue on kuulunut vuosisatoja karjalaisten elinalueisiin, mutta alueelle 
on muuttanut myöhemmin myös suomen puhujia. Ensimmäinen suomen puhujien muuttoaalto koettiin 160o-luvulla, kun Ruotsi sai vuoden 1617 Stolbovan rauhassa Käkisalmen läänin, johon myös Raja-Karjala ja nykyinen Suomen Pohjois-Karjala kuuluivat. Tuolloin alueella eläneet ortodoksiset karjalaiset jättivät suurin joukoin kotiseutunsa ja muuttivat uuden rajan itäpuolelle Aunukseen, Vienaan ja Sisä-Venäjälle (tarkemmin Uusitupa ym. 2017: 70 ja siinä mainitut lähteet). Muutolle on lueteltu historiantutkimuksessa lukuisia syitä, muun muassa ruotsalaisten isäntien ankara verotus ja kaupankäynnin rajoittaminen sekä venäläisten houkuttelu. Tärkein syy lienee kuitenkin ollut se, että Käkisalmen läänin karjalaisia yhdistivät venäjänpuoleisiin karjalaisiin yhteinen kieli, karjala, ja yhteinen uskonto, ortodoksisuus, jonka harjoittaminen vaikeutui uusien luterilaisten isäntien alaisuudessa. (Esim. Kuujo 1963: 54; Saloheimo 1986 [1976]: 9-14; Kirkinen 1994: 131-133.) 160o-luvulla tapahtuneen muuton seurauksena nykyisen Pohjois-Karjalan alueelle karjalankielisiä ortodokseja jäi lähinnä vain Liperin Taipaleen kylään ja Ilomantsin itäosiin. Alue sai uusia asukkaita Savosta, Pohjanmaalta ja EteläKarjalasta, ja uusien asukkaiden myötä alue luterilaistui uskonnoltaan ja savolaistui kieleltään. Toki Raja-Karjalastakin muutettiin rajan yli Venäjälle ja myös Raja-Karjalaan muutti uutta väestöä lännestä, mutta väestön vaihtuminen ei ollut yhtä dramaattista kuin Pohjois-Karjalan alueella. Varsinkin itäisimmät Raja-Karjalan osat säilyivät vielä 160o-luvulla täysin ortodoksisina. (Saloheimo 1986 [1976]: 80; 2010: 52-55; Leskinen 1998: $359-363,373-375$.)

Toinen, seurauksiltaan vieläkin merkittävämpi suomen puhujien muuttoaalto RajaKarjalaan käynnistyi Suomen itsenäistyttyä. Suomen autonomian aikana rajakarjalaiset olivat olleet edelleen kiinteissä kontakteissa rajan itäpuolella elävien Aunuksen karjalaisten kanssa: rajan yli käytiin kauppaa, kuljettiin töissä ja praasniekoissa, vierailtiin sukulaisissa sekä solmittiin avioliittoja (esim. Hämynen 1993: 61-64). Suomen itsenäistyttyä raja kuitenkin sulkeutui ja rajakarjalaisten vuosisataiset kontaktit itään katkesivat äkillisesti. Samaan aikaan Suomen valtionjohto katsoi tärkeäksi kytkeä rajamaakunta nopeasti muun valtion yhteyteen, ja Raja-Karjalan kontakteja länteen alettiin määrätietoisesti vahvistaa. Ennen Suomen itsenäistymistä Raja-Karjalassa oli ollut sekä suomen- että venäjänkielisiä kouluja. Nyt venäjänkieliset koulut lakkautettiin ja kaikki rajakarjalaiset ohjattiin suomalaisiin kansakouluihin. Myös liikenneyhteyksiä länteen parannettiin: rakennettiin sekä uusia maanteitä että rautatie aina maakunnan itäisimpään pitäjään saakka. Rata Suojärvelle valmistui vuonna 1922, ja se mahdollisti RajaKarjalan itäisimpienkin osien metsävarojen valjastamisen teollisuuden käyttöön. Rataa pitkin voitiin kuljettaa sekä puuta että työvoimaa, ja alueelle saapuikin työläisiä ympäri Suomen. Kaikella tällä oli olennainen merkitys myös alueen kielelliseen maisemaan. (Tarkemmin Uusitupa ym. 2017: 71-72.)

Eri tutkimuksissa on esitetty vaihtelevia arvioita siitä, miten 1900-luvun ensimmäisten vuosikymmenten suomalainen muuttoaalto Raja-Karjalaan ehti vaikuttaa perinteiseen rajakarjalaiseen kulttuuriin ja kieleen ennen toista maailmansotaa (Jeskanen 2005; Turunen 1982; Leskinen 1998). Suhteellisen yksimielisiä tutkijat ovat kuitenkin siitä, että suurin kielellinen ja kulttuurillinen muutos tapahtui sotien jälkeen, kun rajakarjalaisten oli jätettävä kotiseutunsa ja asetuttava asumaan uusille asuinsijoille Pohjois-Karjalaan, Pohjois-Savoon, Kainuuseen ja Oulun seudulle. Asuttamisessa pyrittiin huomioimaan 
vanhan asuinpaikan luonnonolot ja olemassa olevat sosiaaliset verkostot, mutta usein vanhat kylä- ja seurakuntayhteisöt kuitenkin pirstoutuivat eikä karjalankielisen siirtoväen erityislaatuisuutta otettu esimerkiksi kouluopetuksessa huomioon. (Uusitupa ym. 2017: 72-73.)

Välittömästi sotaa seuranneina vuosikymmeninä vakiinnutettiin tapa puhua sodasta toipumisesta ja siirtoväen asuttamisesta positiivisessa sävyssä, eräänlaisena kansallisena menestystarinana. Todellisuudessa monista siirtoväen asemaa ja kohtelua koskeneista epäkohdista kuitenkin vain vaiettiin, ja vasta 1900-luvun viimeisillä vuosikymmenillä tutkimus alkoi nostaa esiin myös vaihtoehtoisia historioita. Viime vuosikymmeninä tehty siirtoväen sopeutumista koskeva tutkimus on osoittanut, että monet varsinkin ortodoksiseen uskontoon liittyvät tavat ja perinteet saattoivat tuntua paikkakuntalaisista oudoilta, vierailta ja venäläisiltä, mikä ei tietenkään ollut omiaan vähentämään uusia tulokkaita kohtaan koettuja ennakkoluuloja (mm. Raninen-Siiskonen 1999, Kananen 2010). Myöskään karjalan kieli ei saanut osakseen ymmärrystä, saati virallista tukea. Vaikka kielitieteilijät ovat määritelleet suomen ja karjalan erillisiksi kielikseen jo 180o-luvulla, Suomessa vallitsi sotavuosina ja pitkään sotavuosien jälkeen käsitys, että karjala on yksi suomen murre (esim. Hakulinen, Kalima \& Uotila 1942). Suhtautuminen karjalan kieleen Suomessa onkin vaihdellut eri aikoina sen mukaan, millainen on ollut maailmanpoliittinen ja yhteiskunnallinen tilanne ja millaisia intressejä ja pyrkimyksiä valtaapitävillä on kulloinkin ollut.

Olen kerännyt tutkimusaineistoni 1960- ja 1970-luvuilla tehdyistä murrehaastatteluista, jotka kuuluvat Suomen kielen nauhoitearkiston kokoelmiin. Arkisto perustettiin vuonna 1959, jolloin kielitieteilijöiden keskuudessa vallitsi huoli siitä, että vanhat murteet ovat katoamassa. Tästä syystä kaikista Suomessa puhuttavista murteista haluttiin kiireen vilkkaa tallentaa materiaalia äänitearkistoon. Tavoitteeksi asetettiin 30 nauhoitetunnin kokoaminen jokaisesta suomenkielisestä pitäästä, ja tähän tavoitteeseen päästiinkin 1970-luvun lopulla. (Kotus 2017.) Murrehaastatteluja tekivät kieliaineiden ylioppilaat ja tutkijat, jotka kiersivät paikkakunnilla kesäisin ja yrittivät löytää haastateltavikseen mahdollisimman vanhoja ja koko ikänsä samalla paikkakunnalla eläneitä ihmisiä (Yli-Paavola 1970: 35$60)$.

Muiden Suomen murrealueiden tavoin nauhoitearkistoon haastateltiin myös Raja-Karjalasta kotoisin olevaa siirtoväkeä. Rajakarjalaismurteita äänitettiin 196o- ja 70-luvuilla noin 550 tuntia, ja tästä aineistosta 119 tuntia on litteroitu Itä-Suomen yliopistossa 2000-luvulla (Raja-Karjalan korpus). Aikaisemmin rajakarjalaishaastatteluja ei ole juuri hyödynnetty tutkimuksessa. Kaiken kaikkiaan rajakarjalaismurteita ja Suomessa puhuttua karjalaa on tutkittu hyvin vähän ennen 2000-lukua. Esimerkki 5 on erään impilahtelaisen haastattelusta. Puhuja on edellä kertonut elämästään Impilahdella jatkosodan aikana ja päättää nyt henkilökohtaiseen kokemukseensa perustuvan kertomuksen jaksolla, jossa hän käyttää avoimia yksikön 2. ja 3. persoonan persoonaviittauksia ja yleistää menneiden aikojen ajattelemisen myös muita 'näin vanhoja' koskevaksi tavaksi.

(5) ja myö sillein elimmä dä leivän kans elimmä dä hyvä oĺ. Jumalalla kiitos. voi voi kyllä siinä ihmizen elämäss_om monda vaihetta. näiv vanhaks ku elät ńi sidä, toisin ajon, muate käyt kun, yön ei ńukut [o:aa] eihä ainas ńukuta [o:aa]. 
ni sidä kuundelet ja ajatteled, ńiidä männeidä ja kaikkii jotta voi hyvä izä tok jotta, kyllä ne meijän siellä, kuga on muan alla gu tiijettäz jotta, myö oomma ne päivät kaikki nähneid ja olleit ńi. (IMPILAHTI 7481:1b.)²

Esimerkissä 6 eräs toinen impilahtelaishaastateltava kertoo, miten hänen isällään oli tapana säännöstellä lasten sokerin syömistä: sokeria ei saanut ottaa paljon, ja yhdellä pienellä sokerin murusella piti juoda kahvikupillinen tai kaksikin. Esimerkin päättävä imperatiivilause ei ole nyt käsky tai kehotus vastaanottajalle vaan rajakarjalaismurteille tyypillinen tapa ilmaista, että jonkin toiminnan suorittaminen oli puheena olevassa tilanteessa välttämätöntä ('oli juotava').

(6) ja sitte ei sogerii soanut ottoa palluu. meängi isä pilkko semmoset koĺ ne, neîlän, semmoset neíläkset tuommoń gu oĺ, pala. semmonen gu neíläksen hiä, pieni sen sogerin, ni se yks pień muruńe annettii vua lapsile sokerii. sit juo sil kuppi tahi kaks kupillista, sidä, koffii. mm. (IMPILAHTI 7351:2a.)

Rajakarjalaistaustaisia puhujia haastateltiin aikana, jolloin rajakarjalainen siirtoväki oli elänyt jo vähintään parikymmentä vuotta uusilla asuinsijoillaan poissa RajaKarjalasta. Omassa tutkimuksessani en tarkastele sitä, miten rajakarjalaismurteet ovat mahdollisesti muuttuneet tai suomalaistuneet sotien jälkeisinä vuosikymmeninä, jolloin rajakarjalaiset ovat eläneet uusilla asuinsijoillaan suomen murteiden puhujien keskellä. Sen sijaan olen kiinnittänyt tutkimuksessani huomiota siihen, miten haastattelujen tekoaika arvoineen ja asenteineen näkyy rajakarjalaisten haastateltavien ja heitä useimmiten selvästi nuorempien ja yliopistossa opiskelleiden haastattelijoiden välisessä vuorovaikutuksessa. Kuten kaikessa kielen käytössä myös murrehaastatteluissa puhuja muotoilee ja mukauttaa puhettaan aina suhteessa niihin odotuksiin, jotka puhetilanne ja keskustelukumppani hänen mielestään tilanteelle asettavat. Puhetta suunnitellaan ja muotoillaan siis aina sen mukaan, kuka on vastaanottaja ja mitä hänen taustoistaan tai tilanteelle asettamistaan odotuksista tiedetään. (Ks. myös Karhu 1995; Forsberg 1998: 108.)

Haastateltavan ja haastattelijan välisessä vuorovaikutuksessa näkyy monin tavoin se, että keskustelukumppanit kuuluvat eri sukupolviin ja ovat varttuneet hyvin erilaisissa yhteiskunnissa. Myös tutkimieni lauserakenteiden - eli avoimen tulkinnan saavien yksikön 2. ja 3. persoonan lauseiden - käytössä voi huomata, että nimenomaan keskustelukumppanien erilaiset elämänhistoriat voivat tietyissä kohdin selittää avointen persoonaviittausten käyttöä eli toimia selityksenä sille, miksi puhuja muotoilee puheensa juuri sillä tavalla kuin muotoilee. Kun puhutaan menneisyydestä, puhe ei ole vain menneisyyden asioiden, tapojen ja perinteiden raportoimisesta, vaan samanaikaisesti menneisyyden tapahtumia myös selitetään, arvotetaan ja uudelleen tulkitaan puhehetkisestä näkökulmasta. Menneisyyden tapahtumien ja puhehetken välinen aikaero rakentaa tulkinnallisen perspektiivin, jossa menneisyyden teot ja tapahtumat saavat uusia merkityksiä sen mukaan, millaisina nuo teot ja tapahtumat näyttäytyvät

2. Olen merkinnyt tutkimuksessani avoimen nollan esimerkkeihin 0:Ila, kun se toimii muuna lauseenjäsenenä kuin nominatiivisubjektina. 
puhehetken näkökulmasta (Laitinen 1992: 191, 196-197). Tässä prosessissa hyödynnetään paitsi omia kokemuksia myös kaikkia muita käytössä olevia tiedonlähteitä: muun muassa toisilta ja radiosta kuultuja tarinoita sekä lehdistä luettuja ja koulusta opittuja käsityksiä (Ukkonen 2000, 2002). Murrehaastattelupuheessa onkin kiinnostavaa se, mitä ylipäätään muistellaan, millaisia asioita nostetaan esiin ja millaisia asioita jätetään mainitsematta. Nämä valinnat kertovat siitä, mitkä aiheet puhehetkellä koetaan tärkeiksi, soveliaiksi ja odotuksenmukaisiksi tuoda julki.

Haastateltavan ja haastattelijan välistä vuorovaikutusta tarkatessa käy ilmeiseksi, etteivät keskustelukumppanit ole aina täysin yksimielisiä siitä, mitkä puheenaiheet tilanteessa ovat merkityksellisiä ja keskustelemisen arvoisia. Haastattelijoita kehotettiin ohjaamaan puhetta menneisyyteen ja kyselemään erilaisista vanhoista asioista, koska vanhoista asioista puhumalla uskottiin saatavan äänitteelle myös mahdollisimman vanhaa murretta. Sen sijaan elämästä uusilla asuinsijoilla, mahdollisista sopeutumisvaikeuksista, erilaisuuden tai ulkopuolisuuden kokemuksista tai kielen tai uskonnon takia koetusta syrjinnästä ei murrehaastatteluissa juuri kysellä. Haastateltavat voivat kuitenkin ohjailla keskustelua myös sellaisiin aiheisiin, jotka he itse kokevat tärkeiksi, vaikkei haastattelija niistä kyselisikään. Siitä huolimatta, että molemmat keskustelukumppanit ovat usein selvästi orientoituneita rooleihinsa toisaalta haastateltavana ja toisaalta haastattelijana, näitä tilannerooleja myös haastetaan ja kommentoidaan. Haastateltavakaan ei ole vain kysymyksiin vastailija vaan tilanteen aktiivinen osallistuja, jolla on valta ja mahdollisuus kuljettaa keskustelua haluamilleen poluille.

\section{Lähteet}

\section{Aineslähteet}

Kielitoimiston ohjepankki: Passiivimaisia rakenteita: aina voi yrittää, yleistävä 3. persoona. http://www.kielitoimistonohjepankki.fi/ohje/353 (4.12.2017).

Koivisto, Petri 2013: Naiset ovat koulutetumpia. - Karjalainen 24.3.2013.

KoIvUrANTA, EsA 2017: Joko länsimetron kyytiin vihdoin pääsee? Yle seuraa tiedotustilaisuutta suorana kello 9. - Yle-uutiset 10.11.2017. https://yle.fi/uutiset/3-9925078 (13.12.2017).

MANU, JohannA 2017: Ahneella simasuulla on se kuuluisa loppu. - Yle-uutiset 27.4.2017. https://yle.fi/uutiset/3-9583371 (13.12.2017).

Raja-Karjalan korpus. Noin 119 tuntia Suomen kielen nauhoitearkiston (SKNA) Raja-Karjalan murreäänitteitä litteroituna.

Tutkimuskirjallisuus

Cannelin, Knut 1889: Tutkimus Kemin kielimurteesta. Suomi III:2. Helsinki: Suomalaisen Kirjallisuuden Seura.

Forsberg, Hannele 1998: Suomen murteiden potentiaali. Muoto ja merkitys. Suomalaisen Kirjallisuuden Seuran Toimituksia 720. Helsinki: Suomalaisen Kirjallisuuden Seura.

Forsberg, Hannele - Uusitupa, Milla 2015: Yksikön 2. persoonan avoin käyttö suomen 
murteissa. Esitelmä Kielitieteen päivillä. Vaasa, 21.-23.5.2015.

Hakulinen, Lauri - Kalima, Jalo - Uotila, T. E. (toim.) 1942: Itä-Karjalan murreopas. Ä̈nne- ja muoto-oppia, tekstejä sekä sanastoa. Helsinki: Otava.

Hämynen, TA PIO 1993: Liikkeellä leivän tähden. Raja-Karjalan väestö ja sen toimeentulo 1880-1940. Historiallisia Tutkimuksia 170. Helsinki: Suomen Historiallinen Seura.

ISK = Hakulinen, Auli - Vilikuna, Maria - Korhonen, Rittta - Koivisto, Vesa - Heinonen, Tarja Rittta - Alho, Irja 2004: Iso suomen kielioppi. Suomalaisen Kirjallisuuden Seuran Toimituksia 950. Helsinki: Suomalaisen Kirjallisuuden Seura.

Jeskanen, Matti 2005: Karjalan kieli ja karjalankieliset Suomessa. - Marjatta Palander \& Anne-Maria Nupponen (toim.), Monenlaiset karjalaiset. Suomen karjalaisten kielellinen identiteetti s. 215-285. Studia Carelica Humanistica 20. Joensuu: Joensuun yliopiston humanistinen tiedekunta.

Kananen, Heli KaArina 2010: Kontrolloitu sopeutuminen. Ortodoksinen siirtoväki sotien jälkeisessä Ylä-Savossa (1946-1959). Jyväskylä Studies in Humanities 144. Jyväskylä: Jyväskylän yliopisto.

Kannisto, Artturi 1902: Lauseopillisia havaintoja läntisen Etelä-Hämeen kielimurteesta. Suomi III:20. Helsinki: Suomalaisen Kirjallisuuden Seura.

Karhu, Anna 1995: Murrehaastattelu vuorovaikutustilanteena. - Marjatta Palander (toim.), Murteiden matkassa. Juhlakirja Alpo Räisäsen 6o-vuotispäiväksi s. 92-109. Joensuu: Joensuun yliopiston humanistinen tiedekunta.

Kirkinen, Heik Ki 1994: Karjalan historia juurista Uudenkaupungin rauhaan. - Heikki Kirkinen, Pekka Nevalainen \& Hannes Sihvo (toim.), Karjalan kansan historia s. 13-171. Porvoo: WSOY.

KKS = Karjalan kielen sanakirja I-VI. Lexica societatis fenno-ugricae XVI. Helsinki: Suomalais-Ugrilainen Seura 1968-2005. Verkkoversio. http://kaino.kotus.fi/cgi-bin/kks/ karjala.cgi.

Kotus $2017=$ Kotimaisten kielten keskus: Puhutun kielen aineistot. https://www.kotus.fi/aineistot/puhutun_kielen_aineistot (13.12.2017).

Kuparinen, Heini 2009: Nollapersoonan käyttö eräissä lounaismurteissa. Suomen kielen pro gradu -tutkielma. Turun yliopisto.

KuUjo, ERKк 1963: Raja-Karjala Ruotsin vallan aikana. Joensuu: Karjalaisen Kulttuurin Edistämissäätiö.

LAItinen, LEA 1992: Välttämättömyys ja persoona. Suomen murteiden nesessiivisten rakenteiden semantiikkaa ja kielioppia. Suomalaisen Kirjallisuuden Seuran Toimituksia 569. Helsinki: Suomalaisen Kirjallisuuden Seura.

— 1995: Nollapersoona. - Virittäjä 99 s. 337-358.

Latvala SAlu 1894: Lauseopillisia havaintoja Luoteis-Satakunnan kansankielestä. Helsinki: Suomalaisen Kirjallisuuden Seura.

— 1899: Lauseopillisia muistiinpanoja Pohjois-Savon murteesta. Helsinki: Suomalaisen Kirjallisuuden Seura.

Leskinen, Heik Ki 1998: Karjala ja karjalaiset kielentutkimuksen näkökulmasta. - Pekka Nevalainen \& Hannes Sihvo (toim.), Karjala. Historia, kansa, kulttuuri s. 352-382. Helsinki: Suomalaisen Kirjallisuuden Seura.

RANinen-SiISkonen, TARJA 1999: Vieraana omalla maalla. Suomalaisen Kirjallisuuden Seuran Toimituksia 766. Helsinki: Suomalaisen Kirjallisuuden Seura.

Saloheimo, Veijo 1986 [1976]: Pohjois-Karjalan historia II. 1617-1721. Toinen, korjattu painos. Joensuu: Karjalaisen Kulttuurin Edistämissäätiö. 
2010: Entisen esivallan alle uusille asuinsijoille. Ortodoksikarjalaisten ja inkeroisten poismuutto 1500- ja 1600-luvuilla. Joensuu: Pohjois-Karjalan historiallinen yhdistys.

Sarhima A, Anneli 2017: Vaietut ja vaiennetut. Karjalankieliset karjalaiset Suomessa. Tietolipas 256. Helsinki: Suomalaisen Kirjallisuuden Seura.

SetäL Ä, E. N. 1883: Lauseopillinen tutkimus Koillis-Satakunnan kansankielestä. (Ylipainos Suomi-kirjan Toisen Jakson 16:nnesta Osasta.) Helsinki: Suomalaisen Kirjallisuuden Seura.

Sirelius, U. T. 1894: Lauseopillinen tutkimus Jääsken ja Kirvun kielimurteesta. Helsinki: Suomalaisen Kirjallisuuden Seura.

SurakKa, Anne 2011: Yleistävän yksikön 2. persoonan käyttö inkerinsuomessa. Suomen kielen pro gradu -tutkielma. Itä-Suomen yliopisto.

Turunen, Aimo 1982: Raja-Karjalan murteet. - Yrjö-Pekka Mäkinen \& Ilmari Lehmusvaara (toim.), Karjala 2 s. 65-89. Hämeenlinna: Arvi A. Karisto Oy.

UкKonen, TAInA 2000: Muistitieto tutkimuksen kohteena ja aineistona. - Elore 2/200o. http://www.elore.fi/arkisto/2_oo/ukk2oo.html (13.12.2017).

2002: Mietteitä muistitietohistorian eettisistä ja lähdekriittisistä ongelmista. - Elore 2/2002. http://www.elore.fi/arkisto/2_02/ukk202.html (13.12.2017).

Uusitu PA, Milla 2011: Avoimet persoonaviittaukset rajakarjalaismurteissa. Suomen kielen pro gradu -tutkielma. Itä-Suomen yliopisto.

Uusitupa, Milla - Koivisto, Vesa - Palander, Marjatta 2017: Raja-Karjalan murteet ja raja-alueiden kielimuotojen nimitykset. - Virittäjä 121 s. 67-106.

Yli-Pa Avola, JA а кко 1970: Vuosikymmen kielennauhoitusta. Suomen kielen nauhoitearkiston toiminta 1959-1968. Tietolipas 6o. Helsinki: Suomalaisen Kirjallisuuden Seura.

Milla Uusitupa: Rajakarjalaismurteiden avoimet persoonaviittaukset. Publications of the University of Eastern Finland. Dissertations in Education, Humanities, and Theology 117. Joensuu: University of Eastern Finland 2017. Väitöskirja on luettavissa osoitteessa http://epublications.uef.fi/pub/urn_isbn_978-952-61-2646-3.

Kirjoittajan yhteystiedot: etunimi.sukunimi@uef.fi 